Research Article

\title{
Functional Gene Diversity of Selected Indigenous Hydrocarbon-Degrading Bacteria in Aged Crude Oil
}

\author{
Chioma Bertha Ehis-Eriakha ${ }^{D},{ }^{1}$ Chioma Blaise Chikere, ${ }^{2}$ and Onyewuchi Akaranta ${ }^{3}$ \\ ${ }^{1}$ Department of Microbiology, Edo University Iyamho, Uzairue, Edo State, Nigeria \\ ${ }^{2}$ Department of Microbiology, University of Port Harcourt, Port Harcourt, Rivers State, Nigeria \\ ${ }^{3}$ Department of Pure and Industrial Chemistry, University of Port Harcourt, Port Harcourt, Rivers State, Nigeria
}

Correspondence should be addressed to Chioma Bertha Ehis-Eriakha; bertha_chioma@yahoo.com

Received 26 January 2020; Accepted 2 June 2020; Published 30 July 2020

Academic Editor: Todd R. Callaway

Copyright (c) 2020 Chioma Bertha Ehis-Eriakha et al. This is an open access article distributed under the Creative Commons Attribution License, which permits unrestricted use, distribution, and reproduction in any medium, provided the original work is properly cited.

\begin{abstract}
Crude oil pollution has consistently deteriorated all environmental compartments through the cycle of activities of the oil and gas industries. However, there is a growing need to identify microbes with catabolic potentials to degrade these pollutants. This research was conducted to identify bacteria with functional degradative genes. A crude oil-polluted soil sample was obtained from an aged spill site at Imo River, Ebubu, Komkom community, Nigeria. Bacteria isolates were obtained and screened for hydrocarbon degradation potential by turbidometry assay. Plasmid and chromosomal DNA of the potential degraders were further screened for the presence of selected catabolic genes (C230, Alma, Alkb, nahAC, and PAHRHD $\left.{ }_{(\mathrm{GP})}\right)$ and identified by molecular typing. Sixteen (16) out of the fifty (50) isolates obtained showed biodegradation activity in a liquid broth medium at varying levels. Bacillus cereus showed highest potential for this assay with an optical density of $2.450 @ 600$ nm wavelength. Diverse catabolic genes resident in plasmids and chromosomes of the isolates and, in some cases, both plasmid and chromosomes of the same organism were observed. The $\mathrm{C} 230$ gene was resident in $>50 \%$ of the microbial population tested, while other genes occurred in lower proportions with the least observed in nahAC and PAHRHD. These organisms can serve as potential bioremediation agents.
\end{abstract}

\section{Introduction}

Petroleum hydrocarbons have been identified as a significant group of environmental pollutants in technologically advanced countries. Moreover, the supply of petroleum forms the main sources of energy globally, and it constitutes the major form of environmental pollution during the processes of exploration, mining, purifying, conveying, and marketing petroleum products $[1,2]$. The high alarming rate of petroleum hydrocarbons build-up in the environment has led to menacing human and ecosystem safety such as rescinding soil structures, a detrimental effect on groundwater quality, and deterring plant growth [3].

Crude oil/petroleum hydrocarbons presents diverse physical properties as a result of their complex mixtures of several individual compounds classified based on polarity as saturates, aromatics, resins, and asphaltenes [4-6]. The different crude oil components have varying susceptibility to microbial mineralization based on the structural arrangement. Alkanes are the most susceptible; following this are light aromatics (MAHs), cycloalkanes, heavy aromatics (PAH), resins, and asphaltenes. Generally, alkanes make up about $50 \%$ of crude oil although the source of the oil may alter the concentration [7]. It has been discovered that PAHs are one of the major factors causing the rapid development of cancer as a result of constant exposure to a mixture of highly concentrated PAHs. This has consequently led to the destruction of genetic materials and later stimulates the growth of cancers [8]. Moreover, some PAHs possess numerous health hazards attributes such as genotoxic, carcinogenic, and cytotoxic, especially to aquatic organisms which may be passed onto humans via consumption of sea foods [9]. 
The high rate of exploration and fabrication activities together with inappropriate waste disposal practices has been recognized as the major source of terrestrial and aquatic pollution. Therefore, it has become an imperative search for a sustainable remediation technique that could help in ecorestoration of these polluted environments, especially total petroleum hydrocarbon and polycyclic aromatic hydrocarbons. The remediation of these polluted environments has become the major research focus in the field of science, engineering, and environmental science $[10,11]$.

Bioremediation has been discovered as a type of biodegradation that utilizes beneficial microorganisms for detoxification and the complete removal of inorganic and organic-inorganic xenobiotic compounds from heavily polluted soil. The process of microbial bioremediation involves the utilization of microbial enzymes for biodegradation of these harmful substances from the contaminated soil into innocuous substances [12]. The utilization of hydrocarbon-degrading bacteria which are domicile in these hydrocarbon-polluted soil might be a sustainable, cost-effective, eco-friendly biotechnological tool for the ecorestoration of these oil-polluted soils [13]. This process is essential for adequate reduction of accidental hydrocarbon discharges and for effective protection of these limited resources available in several countries [4]. Myriad of research studies have been conducted to justify the recalcitrance of PAHs and other persistent components of crude oil in the environment. Based on documented research findings, diverse groups of the microbial population present in different environmental compartments have shown potentials to degrade low and high-molecular weight (naphthalene, acenaphthene, anthracene, fluoranthene, pyrene, chrysene) hydrocarbons as the energy source using different mechanisms mediated by enzymes (catabolic genes). Prior to the initiation of bioremediation in a polluted site, it is imperative to determine the presence of active microbes with requisite catabolic genes to effectively drive the remediation process. The presence of these genes, type, and location on specific degradative microbes will provide a guide to how the bioremediation process can be enhanced.

Due to high diversity and complexity of hydrocarbons, degradation of each component is activated by a specific enzyme, for example, the nahAC gene codes for the breakdown of naphthalene and alkB codes for alkanes, while phnAC codes for phenanthrene degradation. Numerous reviews have documented the physiological and enzymatic mechanisms microbes use in the mineralization and degradation of petroleum hydrocarbons [14-16] and observed that different enzymes code for the degradation pathways. An aerobic degradation pathway for petroleum hydrocarbon requires oxygenase enzyme which incorporates oxygen atoms into the hydrocarbons. One or two oxygen atoms can be introduced into the substrate referred to as monooxygenases or dioxygenases, respectively. Oxygen, as an electron acceptor, facilitates the process of aerobic degradation than anaerobic degradation which uses alternate electron acceptors such as nitrate [17-20]. The pathway for aliphatic degradation first produces alcohol that is oxidised through dioxygenases to carboxylic acids which subsequently goes through $\beta$-oxidation to produce $\mathrm{CO}_{2}$ and water. Alternatively, aromatic hydrocarbon degradation occurs through the hydroxylation of a ring mediated by mono- or dioxygenase enzymes to produce diol. Afterwards, the ring is cleaved and further degraded to form catechol or a structurally related compound. Once formed, catechol can be degraded resulting in compounds that can enter into the citric acid (TCA) cycle. The end point of this process is also $\mathrm{CO}_{2}$ and water [18-20].

The application of phylogenetic analyses in the study of whole bacteria diversity using 16S rRNA genes is very essential although this technique may not reveal the specific key players involved in petroleum hydrocarbon degradation, as well as highlights the relationship between the microbial community structure and function. However, an alternative approach to this is the integration of I6S rRNA gene information with the results of functional catabolic gene diversity responsible for the mineralization process [21]. This approach reduces the challenges associated with studying the hydrocarbon-degrading microbial community structure, especially highlighting the link between the microbial community and its functions.

In view of those mentioned above, this study scrutinized the functions of various bacterial communities responsible for the degradation of petroleum hydrocarbons and their specific degradative functions. In addition, we isolated, identified, and characterized the indigenous hydrocarbon utilizing bacteria and their community dynamics which are responsible for the biodegradation of petroleum hydrocarbons using culture-dependent and molecular techniques.

\section{Materials and Methods}

2.1. Sampling and Soil Characterization. Crude oil-polluted soil was collected from an aged spill site at Imo River, Ebubu, Komkom community, Rivers State, Nigeria (Figure 1), using a soil auger machine at different depths $(0.5 \mathrm{~m}, 1 \mathrm{~m}, 1.5 \mathrm{~m}$, and $2 \mathrm{~m}$ ) from different points. Soil samples were bulked together for homogeneity and transferred to the laboratory for analysis within $6 \mathrm{~h}$ of collection. Preliminary characteristics of the soil were evaluated using the standard method described by the American Public Health Association (APHA) $20^{\text {th }}$ Edition 2008, American Society for Testing and Materials (ASTM) $2^{\text {nd }}$ Edition 2007, and Environmental Protection Agency (EPA, 2003).

\subsection{Determination of Total Petroleum Hydrocarbons (TPH)} and Polycyclic Aromatic Hydrocarbons (PAH). Residual TPH and $\mathrm{PAH}$ were extracted from the samples and quantified using a gas chromatograph-flame ionization detector (GCFID). Residual TPHs were extracted with $20 \mathrm{ml}$ of n-pentane from $10 \mathrm{~g}$ of each soil sample. The samples were shaken for $15 \mathrm{~min}$ by using the ultrasonic apparatus and allowed to settle for $60 \mathrm{~min}$ at room temperature. Organic extract 


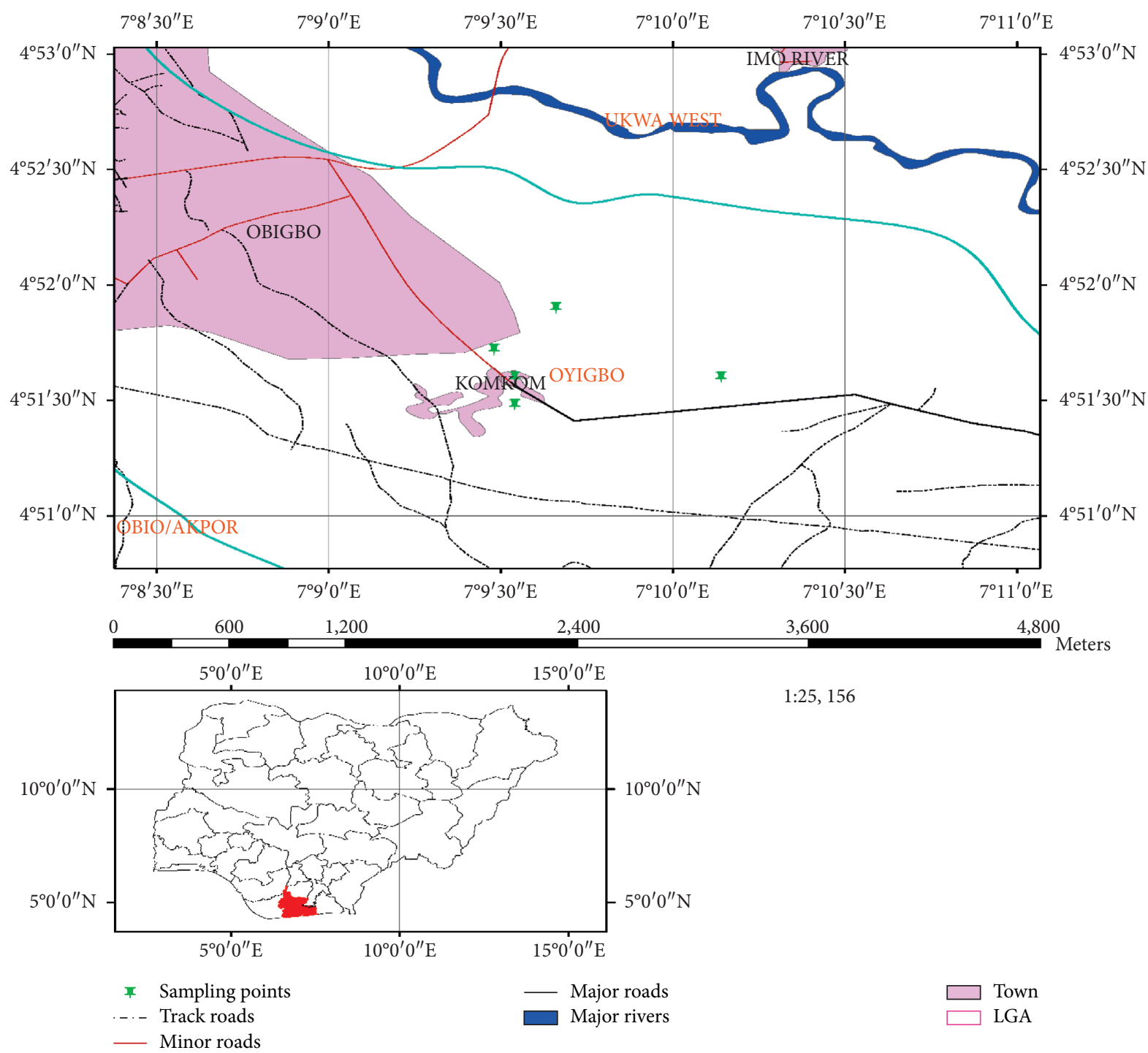

FIGUre 1: Komkom Community, Oyibo LGA of Rivers State showing the different sampling points.

$(10 \mathrm{ml})$ was transferred into a vial and analyzed by GC-FID. GC-FID analysis of TPH and PAH was performed on a Hewlett Packard 5890 Series II-Plus gas chromatograph equipped with an HP 7673 autosampler and FID detector coupled with a $30^{\prime} 0.32 \mathrm{~mm}$ DB-5 (5\% phenyl, 95\% methylpolysiloxane) fused silica capillary column. The oven temperature was programmed from $40^{\circ} \mathrm{C}\left(3 \mathrm{~min}\right.$.) to $300^{\circ} \mathrm{C}$ at $15^{\circ} \mathrm{C} / \mathrm{min}$. Samples were injected in the splitless mode, with the relay open at $20 \mathrm{~S}$. Injector and detector temperatures were 250 and $320^{\circ} \mathrm{C}$, respectively. Helium was used as the carrier gas at a linear velocity of $38 \mathrm{~cm} \mathrm{sec}^{-1}$ (15 psig). Data handling was performed with Agilent Chemstation chromatography software (version 10). For quantification purposes, the peak area for TPH was determined using forced line integration with Agilent Chemstation software between $n$-hexane ( $n$-C6) through $n$-pentatriacontane $(n$-C35) or until the last peak eluted in the chromatographic profile. For individual $\mathrm{PAH}$, the area of each peak was calculated using the baseline-baseline mode and external response factor quantization [22].
2.3. Enumeration of Total Culturable Heterotrophic and Hydrocarbon-Utilizing Bacteria (THB and THUB). For THB counts, $1 \mathrm{~g}$ of soil (wet weight) was homogenized in normal saline $(0.85 \%)$ with a vortexing machine. Ten-fold decimal dilutions of the suspensions were plated out on Plate Count Agar and incubated at $30^{\circ} \mathrm{C}$ for $24 \mathrm{~h}$. For THUB counts, culture enrichment was performed by adding $1 \mathrm{~g}$ of soil into $100 \mathrm{ml}$ of Bushnell Haas Mineral Salts (BHMS) amended with $0.5 \%$ crude oil $(\mathrm{v} / \mathrm{v})$ as the carbon source. The medium was incubated for 5 days at $37^{\circ} \mathrm{C}, 130 \mathrm{rpm}$ for 5 days in a shaker incubator. Thereafter, serial dilution was performed, and the inoculum was plated out on Bushnell Haas agar amended with crude oil for 5 days [21]. Distinct colonies were enumerated and subcultured into nutrient agar plates for further analysis.

2.4. Determination of Bacterial Hydrocarbon Degradation Potential by Turbidometry. Turbidometry screening was conducted to determine the degradation potentials of the 
individual putative hydrocarbon-utilizing bacterium. Representative bacterial isolates were screened for oil degrading capability under aerobic conditions by inoculating a calibrated loop full of 18-hr old culture of each isolate into Bushnell Haas Mineral Salt Broth containing 1\% Bonny light crude oil in a shaker incubator $(150 \mathrm{rpm})$ at $30^{\circ} \mathrm{C}$ for 21 days. Optical density readings, which are a function of biomass increase, were taken at days $0,3,6,11,16$, and 21 , respectively, using a calibrated spectrophotometer at $600 \mathrm{~nm}$ wavelength against water as blank. Biodegradation potential of each bacterium was scored by turbidity of the media and emulsification of oil in a mineral broth medium and by visual observation of breakdown of the crude oil layer [23].

2.5. DNA Extraction and PCR. Genomic DNA and the plasmid used during this study were obtained using the Zymo-Spin Research DNA extraction kit ${ }^{\mathrm{TM}}$ (Inqaba Biotech., Pretoria, South Africa). The $16 \mathrm{~S}$ rRNA (ribonucleic acid) gene amplification and Sanger sequencing techniques were employed to identify the bacterial isolates and characterize the total bacterial community structure in the various microcosms at intervals. PCR was conducted with an Eppendorf thermal cycler (vapo.protect) machine on all DNA extracted samples using universal primer set $27 \mathrm{~F}$ and $1492 \mathrm{R}$ which amplify approximately $1500 \mathrm{bp}$ of the $16 \mathrm{~S}$ rRNA gene sequence targeting variable regions VI and V3 of the $16 \mathrm{~S}$ rRNA gene. The $20 \mu \mathrm{l}$ PCR mixture contained $2 \mu \mathrm{l}$ volume of the extracted DNA, $0.16 \mu \mathrm{l}$ each of $20 \mathrm{pmol}$ of both forward 27F $3^{\prime}$ GAGTTTGATCCTGGCTCAG $5^{\prime}$ and reverse primers 1492R 5'CTCAAACTAGGCCAGTC 3', $10 \mu \mathrm{l}$ of Green Master mix (Taq polymerase, PCR buffer, $\mathrm{MgCl}_{2}$, and dNTPs), and $7.68 \mu \mathrm{l}$ of nuclease-free water. A reaction without template DNA was included as negative control. The PCR program was as follows: a denaturing step at $94^{\circ} \mathrm{C}$ for 5 minutes followed by 30 cycles of $94^{\circ} \mathrm{C}$ for 1 minute, annealing temperature for 1 minute at $55^{\circ} \mathrm{C}$, extension at $72^{\circ} \mathrm{C}$ for 1 minute, and final extension at $72^{\circ} \mathrm{C}$ for 10 minutes and was held at $4^{\circ} \mathrm{C}$. Amplified DNA was examined by electrophoresis in $1.5 \%$ agarose gel with $2 \mu$ laliquots of PCR products in $1 \mathrm{x}$ Tris-Acetate-EDTA buffer and visualized on a UV-trans illuminator.

2.6. Determination of Functional Genes in Plasmid and Chromosomal DNA. Five functional degradative genes targeting alk $\mathrm{B}$ (short and middle chain alkanes, $\mathrm{C}_{8}-\mathrm{C}_{16}$ ), Alma (long chain alkane, $\mathrm{C}_{16}-\mathrm{C}_{36}$ ), catechol 2, 3 dioxygenase (aromatic hydrocarbons), $\mathrm{PAH}-\mathrm{RHD}_{(\mathrm{GP})}$ (aromatic hydrocarbons), and nah AC (naphthalene degrading gene) were used to detect these genes in the putative hydrocarbon utilizing bacteria to determine their catabolic potentials and capabilities. Also, all isolates were analyzed for plasmid and chromosomal DNA to determine the location of the genes. The process involved PCR with the specific genes targeting specific sites on the bacterial genomic and plasmid DNA molecules responsible for the breakdown of different crude oil constituents. PCR programme for all functional gene amplification is shown in Supplementary Tables 1-4.
2.7. Sequencing. Amplified PCR products were purified and sequenced with universal primer set $27 \mathrm{~F}$ and $1492 \mathrm{R}$ using an ABI 3130 XL genetic analyzer incorporating the ABI Big Dye Terminator Cycle sequencing kit version 3.1. Sequencing was performed by Inqaba Biotech, Pretoria, South Africa. The comparison of the nucleotide sequences of the unique fragment with the sequences available in the GenBank database was carried out using the NCBI BLAST program (http//www.ncbi.nlm.nih.gov/blast).

\section{Results}

3.1. Baseline Properties of the Samples. The representative samples of the crude oil-polluted soil were analyzed using physicochemical, gas chromatographic, and microbiological analysis to ascertain the extent of contamination, and GCFID revealed detectable concentrations of TPH and $\mathrm{PAH}$ values as $8695.7723 \mathrm{mg} / \mathrm{kg}$ and $989.1188 \mathrm{mg} / \mathrm{kg}$, respectively, as shown in the chromatograms (Figures 2 and 3 ).

The TPH components in the soil ranged from C10 to C34 with varying concentrations of carbon components (Table 1), while PAH components were benzo(b)fluoranthene (56.94), acenaphthylene (45.09), benzo(k)fluoranthene (78.93), fluorine (197.62), acenaphthene (58.77), benzo(a) anthracene (115.84), indeno (1,2,3 - d)pyrene (67.56), dibenz(a,h)anthracene (26.32), pyrene (100.63), phenanthrene (78.85), chrysene (20.32), naphthalene (17.76), benzo(a)pyrene (45.07), benzo(g, h,i)perylene (25.17), and anthracene (13.00) (Table 2). Other parameters analyzed include $\mathrm{pH}$ (5.97), E.C. (60 $\mu \mathrm{s} / \mathrm{cm})$, moisture content $(2.4 \%)$, nitrate $(0.46 \mathrm{mg} / \mathrm{kg})$, phosphate $(18.24 \mathrm{mg} / \mathrm{kg})$, TOC $(31.4 \%)$, nickel $(2.4 \mathrm{mg} / \mathrm{kg})$, lead $(1.83 \mathrm{mg} / \mathrm{kg})$, and zinc $(52.50 \mathrm{mg} / \mathrm{kg})$. Baseline total heterotrophic bacteria (THB) and total hydrocarbon-utilizing bacteria (THUB) counts using standard microbiological methods were observed to be $3.11 \times 10^{8} \mathrm{cfu} / \mathrm{g}$ and $2.43 \times 10^{8} \mathrm{cfu} / \mathrm{g}$, respectively.

\subsection{Assessment and Evaluation of Degradation Potential.} Degradation assay was conducted to determine the biodegradation potential of putative hydrocarbon-utilizing bacteria isolated from the crude oil-contaminated soil. The optical density readings were at variance across all bacterial isolates at different days. Isolates showed variations in the degradation rate of crude oil in a liquid broth medium, and this was scored based on visual observation of turbidity, emulsification of the crude oil, and optical density obtained with a spectrophototometer (600 nm wavelength), as presented in Figure 4. At the end of the experiment, a significant population of the bacteria isolates showed maximum degradation. These degrading capabilities discovered revealed that the microorganisms isolated from the polluted site were able to utilize crude oil as the source of energy and carbon. The cells were able to increase within the days of study, indicating utilization of oil for their growth and development and, hence, the concomitant increase in the concentration of the broth (turbidity).

Isolate HDB5 (Bacillus cereus strain Z-5) showed highest potential for crude oil degradation (2.450), while HDB 1 


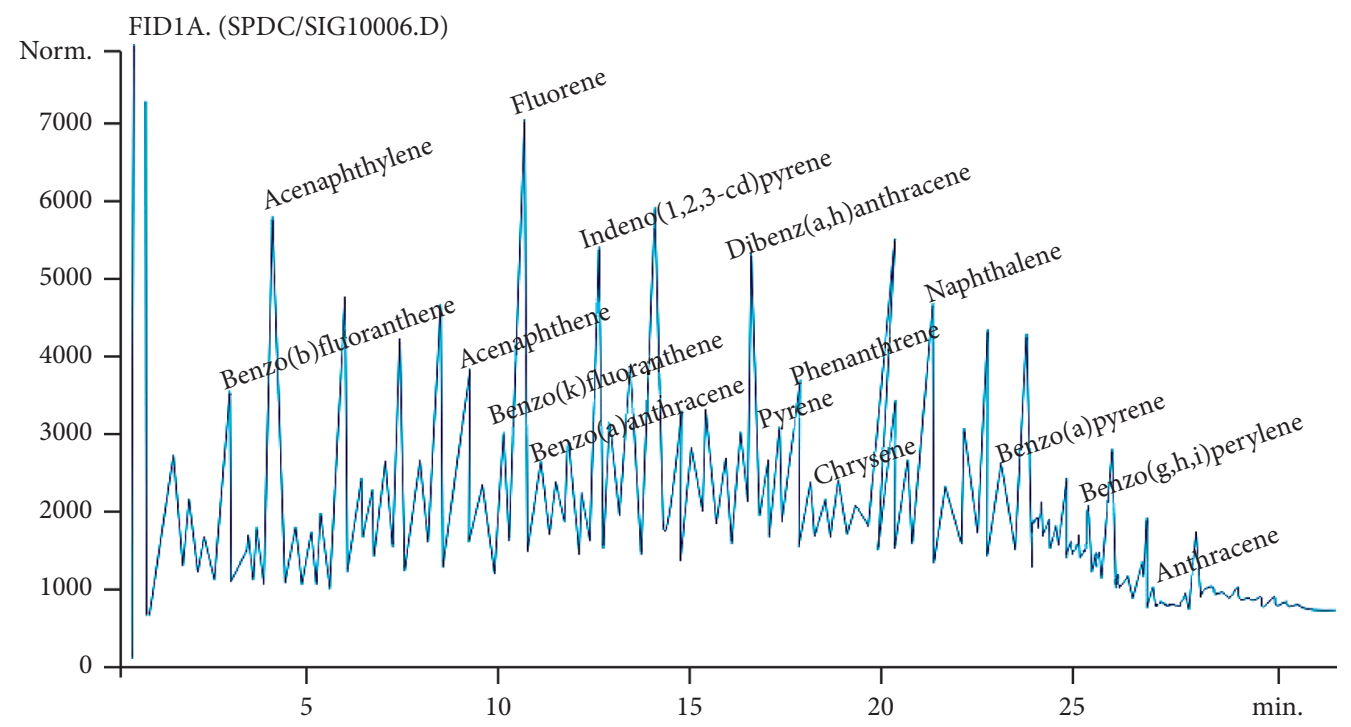

FIGURE 2: Baseline chromatogram of the polycyclic aromatic hydrocarbons profile of the soil sample.

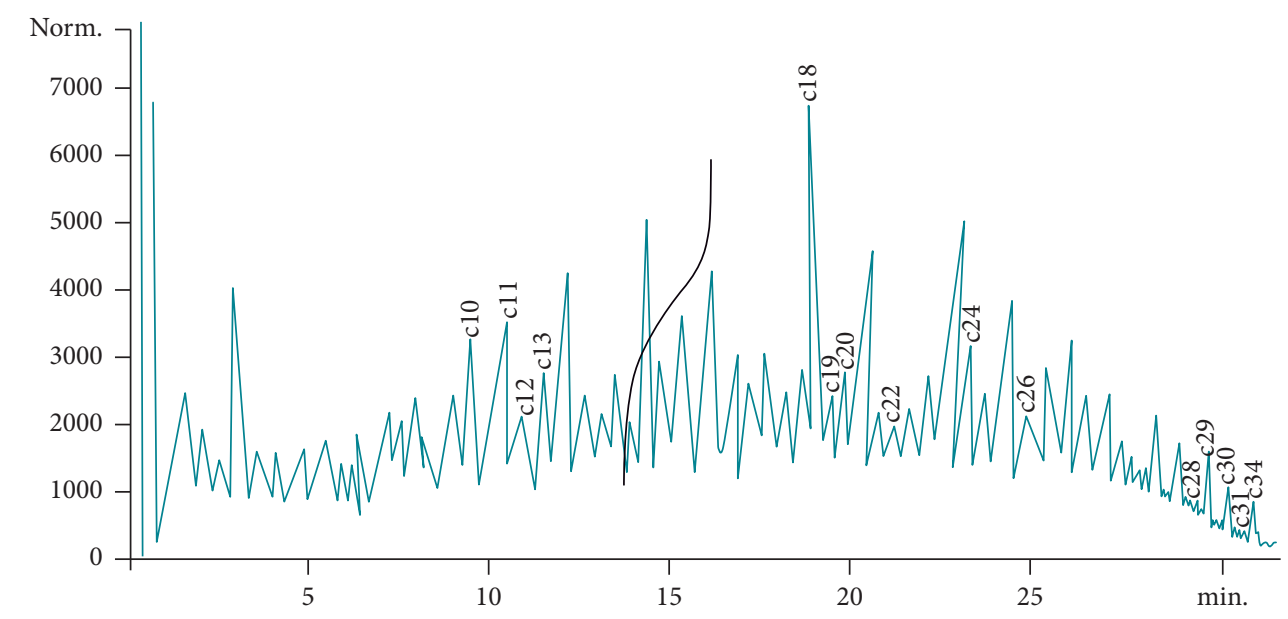

FIgURE 3: Baseline chromatogram of the total petroleum hydrocarbons profile of the soil sample.

TABle 1: Polycyclic aromatic hydrocarbon components of soil.

\begin{tabular}{lc}
\hline PAH component & Conc. \\
\hline Benzo(b)fluoranthene & 56.94305 \\
Acenaphthylene & 45.06849 \\
Acenaphthene & 58.76505 \\
Benzo(k)fluoranthene & 78.93263 \\
Fluorene & 197.61813 \\
Fluoranthene & - \\
Benz(a)anthracene & 115.83669 \\
Indeno(1, 2, 3-d)pyrene & 67.86253 \\
Dibenz(a,h)anthracene & 26.68901 \\
Pyrene & 100.62592 \\
Phenanthrene & 78.84827 \\
Chrysene & 20.32951 \\
Naphthalene & 17.76326 \\
Benzo(a)pyrene & 45.06849 \\
Benzo(g, h, i)perylene & 25.16782 \\
Anthracene & 13.00487 \\
Total & $\mathbf{9 8 9 . 1 1 8 8 9}$ \\
\hline
\end{tabular}

showed the least degradation efficiency (0.194). The control which contained just crude oil in the liquid broth medium without the test organism was 0.193 at day 21 .

3.3. Bacterial Identification Based on Sanger Sequencing. Amplified PCR products (16S rRNA) were purified and sequenced. Electropherograms obtained from the sequence were called using chromas Lite version 2.01 software. Identification of bacterial $16 \mathrm{~S}$ rRNA sequences was aligned with BLAST search facility of National Centre for Biotechnology information (NCBI) databases. The sequences aligned gave $99-100 \%$ similarity with those deposited in GenBank and as such considered close relatives and assigned identities. Sixteen (16) amplicons yielded good sequences whose identities have been assigned. The sequence result obtained is presented in Table 3. All isolates belonged to the domain bacteria. Bacteria isolates predominantly belonged to two (2) phyla, three (3) classes, and eleven (11) genera. The 
TABLE 2: Total petroleum hydrocarbon components of the polluted soil.

\begin{tabular}{lc}
\hline TPH & Conc. $(\mathrm{mg} / \mathrm{kg})$ \\
\hline c8 & - \\
c9 & - \\
c10 & 1116.36824 \\
c11 & 423.27828 \\
c12 & 155.13926 \\
c13 & 509.20511 \\
c14 & - \\
c15 & - \\
c16 & - \\
c17 & - \\
c18 & - \\
c19 & - \\
c20 & 131.58471 \\
c21 & 110.71325 \\
c22 & 0.00000 \\
c23 & 827.41236 \\
c24 & 0.00000 \\
c25 & 2006.25633 \\
c26 & - \\
c27 & 105.51325 \\
c28 & 0.00000 \\
c29 & 390.47122 \\
c30 & 1294.12988 \\
c31 & 1132.60042 \\
c32 33 & 249.33617 \\
c34 & - \\
Total & - \\
\hline
\end{tabular}

observed phyla, class, and genera and their percentage contributions to the whole are presented in subsequent pages. Nucleotide sequences obtained from this research have been deposited in GenBank database under accession numbers KX809608, KX809649, and KX809653 for all bacterial isolates identified except Cb27. Table 4 illustrates a heatmap distribution of bacterial isolates across all microcosms in the different sampling days.

3.4. Functional Gene Diversity. The presence of hydrocarbon-degrading genes was assessed using PCR amplification with 5 specific primers targeting the $\mathrm{PAH}$ ring hydroxylating dioxygenase gene for Gram-positive bacteria (PAH$\mathrm{RHD}_{(\mathrm{GP})}$ ), ring cleavage dioxygenase gene (catechol 2,3, dioxygenase), naphthalene dioxygenase (nahAC), long chain alkane degrading gene (alma), and midchain alkane monooxygenase (alkB). Biodegradation of n-alkanes and aromatic hydrocarbons efficiency were demonstrated with the presence of positive bands on gel visualized under a transilluminator after amplification of chromosomal and plasmid DNAs in the bacterial isolates. Specific detection of the five functional genes was achieved by combining PCR amplification with short oligonucleotides called primers. The primers target essentially the same regions on the genomic DNA and subsequently amplified with PCR to produce visible bands on gel electrophoresis.

The distribution of functional genes across all bacterial isolates generated is presented in a heatmap (Table 5). The chart also illustrates the number of genes present in each isolate and the location of the genes as regards to the genetic elements (plasmid or chromosome) harbouring the genes. $\mathrm{AlkB}$ and $\mathrm{C} 23 \mathrm{O}$ were highly abundant and redundant in most of the isolates tested. Results revealed that an Enterobacter hormaechei strain PS53C and Pseudomonas knackmussii strain $\mathrm{B} 13$ harboured the highest number of genes across all screened isolates. Generally, Alk B and C230 were the most dominant genes present across all isolates.

\section{Discussion}

The physicochemical parameters tested in this study indicated long-term exposure of the sample to hydrocarbon contamination, and this was significantly evidenced in the low nitrate and phosphate values observed owing to the increase in the hydrocarbon content and a known effect of long-term hydrocarbon pollution. Likewise, the high concentrations of TPH and PAH values in the soil sample indicated substantial pollution of the test sample.

The putative oleophilic bacteria were isolated using the enrichment culture procedure $[21,24]$. It was evident in this study that the utilization of the hydrocarbons by oleophilic bacteria resulted in visual gradual decrease in the crude oil layer in Bushnell Haas broth and a concomitant increase in optical density (absorbance) @ $600 \mathrm{~nm}$ wavelength. The growth dynamics of the organisms in the liquid medium as determined by O.D. showed that $60 \%$ of the isolates grew maximally in the medium with none exhibiting lag phases, and this could be attributed to genetic make-up of the individual bacteria and the constitutive expression of hydrocarbon catalyzing enzymes which may be lacking in the remaining $40 \%$. This result is consistent with the findings of $[21,25,26]$. The poor growth rate and low O.D. reading observed in the $40 \%$ of the bacterial isolates could also be related to substrate specificity [27]. Some oleophilic bacteria are specific for degrading metabolites, by-products of crude oil degradation, or substrates not present in the crude oil composition, and this could have informed the low O.D. readings observed. This further proves that crude oil degradation is more effective and swift when microbes work in consortium (cometabolism) [28-30]. Patowary [30] stated that some members of the microbial community might have the ability to secrete important degradative enzymes and growth factors while others exhibit the potentiality of biosurfactant production leading to enhanced solubilization of hydrophobic hydrocarbons. The production of an extracellular biosurfactant is an underlying mechanism implemented by hydrocarbon degraders to mineralize petroleum hydrocarbons, and this was observed during the turbidometry assay by emulsification of crude petroleum in the broth culture inoculated with the test organisms. It has been repeatedly documented that different strains of Bacillus spp. found in different compartments of the environment produce biosurfactant/bioemuslifiers highly implicated in the degradation of a wide range of hydrocarbon compounds. Other isolates obtained in this study such as Pseudomonas spp., Enterobacter spp., Burkholderia spp., and Acinetobacter 


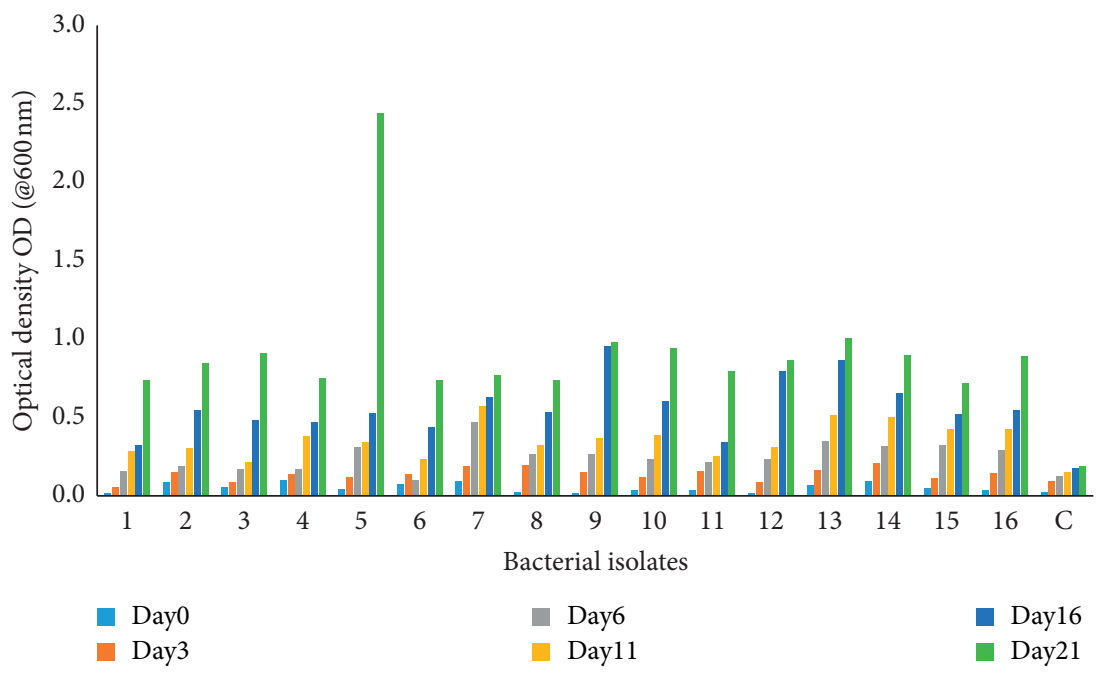

FIGURE 4: Biodegradation activity of bacterial isolates.

TABLE 3: Baseline properties/characteristics of the study site.

\begin{tabular}{lccc}
\hline Parameters & Method & DPR intervention limit & Concentration/quantity \\
\hline $\mathrm{pH}$ & APHA $4500 \mathrm{H}^{+} \mathrm{B}$ & $\mathrm{NA}$ & 5.97 \\
E. conductivity $(\mu \mathrm{s} / \mathrm{cm})$ & Cond. Meter & NA & 60 \\
Moisture content $(\%)$ & BS $1377-2: 1990$ clause 1 & NA & 2.40 \\
Nitrate $\left(\mathrm{NO}_{3}\right)(\mathrm{mg} / \mathrm{kg})$ & APHA 4500- NO $\mathrm{N}^{3-}$ & $\mathrm{NA}$ & 0.46 \\
Phosphate $\left(\mathrm{P}_{2} \mathrm{O}_{5}\right)(\mathrm{mg} / \mathrm{kg})$ & APHA $4500-\mathrm{P}$ & $\mathrm{NA}$ & 18.24 \\
Total organic carbon $(\%)$ & BS $1377-2: 1990$ clause 3 & 10 & 31.4 \\
Nickel $(\mathrm{mg} / \mathrm{kg})$ & ASTM D 1886 & 380 & 2.420 \\
Lead $(\mathrm{mg} / \mathrm{kg})$ & ASTM D 3559 & 210 & 1.283 \\
Zinc $(\mathrm{mg} / \mathrm{kg})$ & ASTM D 1691 & 5000 & 52.50 \\
TPH $(\mathrm{mg} / \mathrm{kg})$ & EPA 8015 & 40 & 8695.77231 \\
PAH $(\mathrm{mg} / \mathrm{kg})$ & EPA 8260 & NA & 989.11889 \\
THB & Spread plate & NA & $3.11 \times 10^{8}$ \\
HUB & Spread plate & $2.43 \times 10^{8}$ \\
\hline
\end{tabular}

Method source: the American Public Health Association (APHA) 20 th Edition 2008, American Society for for Testing and Materials (ASTM), EPA: Environmental Protection Agency. Keys: Cond. Meter: conductivity meter, NA: not available, BS: British Standard, Cfu/g: colony forming unit per gram.

TABLE 4: The 16S rRNA identification of bacterial isolates.

\begin{tabular}{|c|c|c|c|c|c|}
\hline $\begin{array}{l}\text { Isolate } \\
\text { code }\end{array}$ & $\begin{array}{l}\text { Accession } \\
\text { number }\end{array}$ & $\begin{array}{l}\text { Closest relative accession no. } \\
\text { (bases compared) }\end{array}$ & $\begin{array}{l}\text { Similarity } \\
(\%)\end{array}$ & $\begin{array}{l}\text { Phylogenetic } \\
\text { Phylum }\end{array}$ & $\begin{array}{c}\text { Affiliation } \\
\text { Bacterial identity }\end{array}$ \\
\hline $\mathrm{Cb} 1$ & KX809626 & KT021522.1 & 100 & Proteobacteria & Enterobacter hormaechei strain SDI-42 \\
\hline $\mathrm{Cb} 2$ & KX809627 & KX426044.1 & 100 & Proteobacteria & Pseudomonas aeruginosa strain A-1 \\
\hline $\mathrm{Cb} 3$ & KX809628 & KU726513.1 & 99 & Firmicute & Staphylococcus xylosus strain AV1 \\
\hline $\mathrm{Cb} 4$ & KX809629 & KX390638.1 & 100 & Firmicute & Staphylococcus hominis strain H69 \\
\hline $\mathrm{Cb} 5$ & KX809630 & KR697783.1 & 100 & Firmicute & Bacillus cereus strain Z-5 \\
\hline $\mathrm{Cb} 6$ & KX809631 & KT714045.1 & 100 & Firmicute & Bacillus thuringiensis strain VKK-BB-2 \\
\hline $\mathrm{Cb} 7$ & KX809634 & СР014647.1 & 99 & Proteobacteria & Klebsiella pneumoniae strain KPNIH36 \\
\hline $\mathrm{Cb} 8$ & KX809617 & KR349544.1 & 99 & Proteobacteria & Pseudomonas aeruginosa strain VV163 \\
\hline $\mathrm{Cb} 9$ & KX809636 & KC878000.1 & 100 & Proteobacteria & Burkholderia ambifaria strain $R 1$ \\
\hline $\mathrm{Cb} 10$ & KX809638 & NR_121733.1 & 100 & Proteobacteria & Pseudomonas knackmussii strain B13 \\
\hline Cb11 & KX809641 & KX289657.1 & 100 & Proteobacteria & $\begin{array}{c}\text { Pseudomonas stutzeri strain SMG-8_NRB- } \\
\text { DRDO MP }\end{array}$ \\
\hline $\mathrm{Cb} 12$ & KX809642 & KX214111.1 & 100 & Proteobacteria & Acinetobacter baumannii strain 578CR \\
\hline $\mathrm{Cb} 13$ & KX809644 & KT717633.1 & 100 & Proteobacteria & Burkholderia cepacia strain KHD 08 \\
\hline $\mathrm{Cb} 14$ & KX809613 & JX294308.1 & 99 & Proteobacteria & Enterobacter hormaechei strain PS53C \\
\hline $\mathrm{Cb} 15$ & N/A & N/A & N/A & N/A & N/A \\
\hline $\mathrm{Cb} 16$ & KX809623 & LC014122.1 & 100 & Proteobacteria & $\begin{array}{c}\text { Acinetobacter nosocomialis strain: GTC } \\
03313\end{array}$ \\
\hline
\end{tabular}


TABLE 5: Heatmap of functional gene diversity of bacterial isolates located in the plasmid and chromosome.

\begin{tabular}{|c|c|c|c|c|c|c|}
\hline S/no. & Isolates & Alk B & Alma & $\begin{array}{c}\text { PAH- } \\
\mathrm{RHD}_{(\mathrm{GP})}\end{array}$ & $\mathrm{C} 230$ & Nah AC \\
\hline Cb1 & Enterobacter hormaechei strain SDI-42/ & & & & & \\
\hline $\mathrm{Cb} 2$ & Pseudomonas aeruginosa strain A-1 & & & & & \\
\hline $\mathrm{Cb} 3$ & Staphylococcus xylosus strain AV1 & & & & & \\
\hline $\mathrm{Cb} 4$ & Staphylococcus hominis strain $\mathrm{H} 69 /$ & & & & & \\
\hline $\mathrm{Cb} 5$ & Bacillus cereus strain Z-5 & & & & & \\
\hline Cb6 & Bacillus thuringiensis strain VKK-BB-2 & & & & & \\
\hline $\mathrm{Cb} 7$ & Klebsiella pneumoniae strain KPNIH36 & & & & & \\
\hline $\mathrm{Cb} 8$ & Pseudomonas aeruginosa strain VV163 & & & & & \\
\hline Cb9 & Burkholderia cepacia strain KHD 08 & & & & & \\
\hline $\mathrm{Cb} 10$ & Pseudomonas knackmussii strain $\mathrm{B} 13$ & & & & & \\
\hline Cb11 & Pseudomonas stutzeri strain SMG-8_NRB-DRDO MP & & & & & \\
\hline Cb12 & Acinetobacter baumannii strain 578CR & & & & & \\
\hline Cb13 & Burkholderia ambifaria strain R1 & & & & & \\
\hline Cb14 & Enterobacter hormaechei strain PS53C & & & & & \\
\hline Cb15 & Nil & & & & & \\
\hline Cb16 & Acinetobacter nosocomialis strain: GTC 03313 & & & & & \\
\hline \multicolumn{7}{|c|}{ 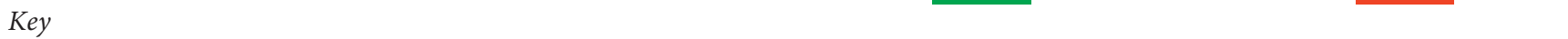 } \\
\hline \multicolumn{7}{|l|}{ Plasmid } \\
\hline \multicolumn{7}{|l|}{ Chromosome } \\
\hline Plasmid + chromosome & & & & & & \\
\hline
\end{tabular}

spp. have been previously documented as biosurfactant producers [31-33].

The presence of high enzymatic capacity allows microbial communities to degrade complex hydrocarbons (aliphatics and polyaromatics) and understanding the microbial functional diversity, and the factors influencing microbial functions is important for bioremediation studies [34]. To underpin the roles of the different bacterial genera isolated from the polluted soil sample and to estimate the genetic diversity contributing to the versatility in the bacterial transformation of hydrocarbon pollutants, bacterial community functional structure was analyzed using five specific genes, namely, alkB, Alma, C230, PAH-RHD $(\mathrm{GP})$, and nahAC. Hydrocarbon-utilizing bacteria isolated from the sample showed that about $50 \%$ of the organisms possessed alkane and catechol 2,3, dioxygenase genes harboured independently in different locations especially the plasmid, while some bacteria possessed specific genes in both locations. In functional genomics, the knowledge of the location of the genes or the genetic element harbouring genes is very important because it serves as a contributing factor to rapid microbial community evolution or adaptation after a spill or environmental perturbation. Both chromosomes and plasmids are genetic elements that harbour functional genes; however, while the former acts as insertion elements, the latter acts as the mobile genetic element facilitating horizontal gene transfer [18-20,35]. Shintani and Nojiri [36] stated that mobile genetic elements (MGEs) are important "vehicles" of diverse genes in the microbial genetic pool. Exchange of MGEs in the microbial community confers new characters to their hosts and encourages swift adaptation to various environments. This explains how over $90 \%$ of the oleophilic bacteria isolated from the aged spill site harboured diverse functional genes, especially alkB and $\mathrm{C} 23 \mathrm{O}$. This result corresponds with the findings documented by [37-39].

Pseudomonas knackmussii B13 was the only bacteria that harboured the nahAC gene in the plasmid, while $\mathrm{PAH}$ $\mathrm{RHD}_{(\mathrm{GP})}$ was present in an unidentified bacterium. The PAH-RHD $(\mathrm{GP})$ are ring hydroxylating genes present in Gram-positive bacteria, and in this study, most of the bacteria isolated were Gram-negative, and this contributed to the presence of one bacterium harbouring the gene. However, a more improved primer system has been developed that targets both PAH-RHD $\alpha$ genes for both Grampositive and Gram-negative [40]. Generally, 90\% of the total bacteria isolated from each microcosm possessed at least a gene and some harboured two or three genes each, while an appreciable number had specific genes located in both the plasmid and chromosome. Most of the genes were located in the plasmid, and this is consistent with the report of Mirdamadia et al. [41] and Shahi et al. [42] which states that the catabolic pathways encoding degradation routes of different aromatic and aliphatic hydrocarbons are frequently located on plasmids. However, oleophilic bacteria isolate Acinetobacter baumannii strain 578CR did not harbour any of the five functional genes tested, although turbidometry screening revealed otherwise. Acinetiobacter is known to be among microbial communities involved in different ecosysytem functions. Several strains of this genus have been attracting growing attention, particularly in bioremediation, especially A. baumannii and A. calcoaceticus [43].

The functional diversity reportedly revealed the presence of catabolic genes that are responsible for aliphatic and aromatic hydrocarbon degradation. In this study, five (5) enzymes coding degradative genes including monooxygenase and dioxygenase responsible for the degradation 
of petroleum hydrocarbons were detected at varied proportions across all isolates. This implies that the inhabiting bacterial population are not only passive or randomly present in the sample but are also actually influenced by the influx of crude oil into the system via pollution [44]. For alkB, the chemical and physicochemical composition of the soils, such as $\mathrm{pH}, \mathrm{TPH}$, organic matter, and/or plant litter, may have influenced the diversity and richness of alkB phylotypes, as suggested by other studies [45-47]. Species of Pseudomonas aeruginosa strain A-1, Staphylococcus xylosus strain AV1, Bacillus thuringiensis strain VKK-BB-2, Pseudomonas aeruginosa strain VV163, Burkholderia cepacia strain KHD 08, Pseudomonas knackmussii strain B13, Burkholderia ambifaria strain R1, Enterobacter hormaechei strain PS53C, and Acinetobacter nosocomialis strain: GTC 03313 harboured the alkB gene. M'rassi et al. [48] isolated and characterized different bacteria strains for bioremediation of environments contaminated with n-alkanes. Bacterial isolates obtained were 150 and mainly affiliated to the Gammaproteobacteria class while the alkB gene was detected in about $80 \%$ of the bacterial strains. Alkanes constitute a higher fraction of the TPH concentration (55\%), and this justifies the global interest in the distribution of alkB in the environment. However, Jurelevicius et al. [47] reported that the diversity of the alkB gene in environmental samples is far from being well studied. The report highlighted that the use of a single pair of primers for PCR quantification of the alkB gene in soil environments limits the range of detection of the genes present. This could be attributed to variations in alkB nucleotide sequences within a bacterial community, and as such, failure to consider the variations will result in a low representation of the diversity and richness of the alkane degrading gene. Shahi et al. [44] evaluated the microbial population and functional genes during the bioremediation of petroleum-contaminated soil as an effective monitoring approach, and the report captured that Gram-negative bacteria and alkB are critical to successful bioremediation. Also, the report stated that failure to maintain the stability of oleophilic bacteria and functional genes will reduce the extent to which alkanes and PAHs are degraded. Additionally, results showed that Alma genes were harboured in five bacterial isolates across and the genes were all located in the plasmid. This is indicative that these organisms have the potential to mineralize long chain alkanes although research has revealed that the Alma gene is more likely to be found in marine hydrocarbon degrading bacterial than terrestrial [49].

The catechol dioxygenase class of bacterial iron-containing enzymes is an example of enzymes implicated in the aerobic mineralization of aerobic aromatic hydrocarbons. This enzyme is involved in aromatic ring cleavage and is responsible for the wide variety of microorganisms that are capable of degrading aromatic compounds [50]. This study witnessed a rapid response to PAHs stress after crude oil contamination. The catabolic gene survey confirmed the enrichment of indigenous community as a result of the influx of high concentration of $\mathrm{PAH}$ into the soil during crude oil pollution. Thomas et al. [51] detected $\mathrm{C} 23 \mathrm{O}$ in isolates affiliated with three closely related taxonomic subgroups within the Pseudomonas group. He et al. [52] characterized the diversity and distribution pattern of $\mathrm{C} 23 \mathrm{O}$ in surface sediments of the Bohai sea. The results showed that sediments of the Bohai sea were dominated by genes related to $\mathrm{C} 23 \mathrm{O}$. Kasuga et al., Olukunle et al., and Baruah et al. [53-55] detected the presence of the $\mathrm{C} 23 \mathrm{O}$ gene in bacteria isolated from different environments polluted with petroleum hydrocarbons. The presence of these degradative genes in the various hydrocarbon-utilizing bacteria isolated from the polluted site indicates the possible application of these microbes in bioremediation and ecorestoration of crude oil-polluted sites.

\section{Conclusions}

In this study, the biodegradability potential of indigenous hydrocarbon-degrading bacteria isolated from an aged spill site was detected by turbidometry assay. Bacillus cereus strain Z-5 showed the highest potential amongst other isolates tested. The functional gene diversity of the isolates revealed diverse catabolic genes (aliphatic and aromatic) residing in the plasmids, chromosomes, and, in some cases, both plasmid and chromosomes of the organisms. However, the C230 gene was resident in $>50 \%$ of the microbial population tested. This report reveals that there is no direct relationship between the biodegradability potential of microbes in a liquid mineral salt broth medium and functional gene diversity. For example, Bacillus cereus strain Z-5 which had the highest optical density value in turbidometry screening only harboured one gene (Alma) amongst the five genes used in this study although other possible genes not accounted for could be the reason for such degrading potential displayed. The results reveals that the crude oil polluted site in komkom community, Rivers State, Nigeria, is a hub for hydrocarbon degrading organisms, and since most the genes that codes for this function were shown to be resident in the plasmid, there is a strong likelihood of horizontal gene transfer occurring at the site and a possible increase in the population of hydrocarbon degraders over time. This information could be harnessed as baseline for a more improved study and possible remediation of the site.

\section{Data Availability}

The data (tables and figures) used to support the findings of this study are included within the article.

\section{Conflicts of Interest}

The authors declare no conflicts of interest.

\section{Authors' Contributions}

All authors have contributed to the research of this manuscript and given approval for the final version of the manuscript.

\section{Supplementary Materials}

PCR conditions for functional genes in plasmid and chromosomal DNA: five functional degradative genes targeting 
alk B (short and middle chain alkanes, $\mathrm{C}_{8}-\mathrm{C}_{16}$ ), Alma (long chain alkane, $\mathrm{C}_{16}-\mathrm{C}_{36}$ ), catechol 2, 3 dioxygenase (aromatic hydrocarbons), $\mathrm{PAH}-\mathrm{RHD}_{(\mathrm{GP})}$ (aromatic hydrocarbons), and nah AC (naphthalene-degrading gene) were used to detect these genes in the putative hydrocarbon-utilizing bacteria to determine their catabolic potentials and capabilities. Also, all isolates were analyzed for plasmid and chromosomal DNA to determine the location of the genes. The process involved PCR with the specific genes targeting specific sites on the bacterial genomic and plasmid DNA molecules responsible for the breakdown of different crude oil constituents. The PCR programme for all functional gene amplifications is shown in Tables 1-4. (Supplementary Materials)

\section{References}

[1] R. Margesin, D. Labbé, F. Schinner, C. W. Greer, and L. G. Whyte, "Characterization of hydrocarbon-degrading microbial populations in contaminated and pristine alpine soils," Applied and Environmental Microbiology, vol. 69, no. 6, pp. 3085-3092, 2003.

[2] E. E. Diplock, D. P. Mardlin, K. S. Killham, and G. I. Paton, "Predicting Bioremediation of Hydrocarbons: Energy Information Administration," Report No. DOE/EIA-0484(2010), US Department of Energy, Washington, DC, USA, http:// www.eia.doe.gov/oiaf/ieo/index.html, 2010.

[3] R. B. Meagher, "Phytoremediation of toxic elemental and organic pollutants," Current Opinion in Plant Biology, vol. 3, no. 2, pp. 153-162, 2000.

[4] N. Das and P. Chandran, "Microbial degradation of petroleum hydrocarbon contaminants: an overview," Biotechnology Research International, vol. 2011, Article ID 941810, 13 pages, 2011.

[5] A. E. Ite, U. J. Ibok, M. U. Ite, and S. W. Petters, "Petroleum exploration and production: past and present environmental issues in the Nigeria's Niger delta," American Journal of Environmental Protection, vol. 1, no. 4, pp. 78-90, 2013.

[6] B. M. Macaulay and D. Rees, "Bioremediation of oil spills: a review of challenges for research advancement," Annals of Environmental Science, vol. 8, pp. 9-37, 2014.

[7] J. D. Van Hamme, A. Singh, and O. P. Ward, "Recent advances in petroleum microbiology," Microbiology and Molecular Biology Reviews, vol. 67, no. 4, pp. 503-549, 2003.

[8] M. D. Khan, H. Abdulateif, I. M. Ismail, S. Sabir, and M. Z. Khan, "Bioelectricity generation and bioremediation of an azo-dye in a microbial fuel cell coupled activated sludge process," PLoS One, vol. 10, no. 10, Article ID e0138448, 2015.

[9] C. A. Menzie, B. B. Potocki, and J. Santodonato, "Exposure to carcinogenic PAHs in the environment," Environmental Science \& Technology, vol. 26, no. 7, pp. 1278-1284, 1992.

[10] Q. Chaudhry, M. Blom-Zandstra, S. K. Gupta, and E. Joner, "Utilising the synergy between plants and rhizosphere microorganisms to enhance breakdown of organic pollutants in the environment (15 pp)," Environmental Science and Pollution Research - International, vol. 12, no. 1, pp. 34-48, 2005.

[11] K. Euliss, C.-H. Ho, A. P. Schwab, S. Rock, and M. K. Banks, "Greenhouse and field assessment of phytoremediation for petroleum contaminants in a riparian zone," Bioresource Technology, vol. 99, no. 6, pp. 1961-1971, 2008.

[12] J. C. Philp, A. S. Whitely, L. Ciric, and M. J. Bailey, "Monitoring bioremediation," in Bioremediation: Applied Microbial Solutions for Real-World Environmental Cleanup, R. M. Atlas and J. Philp, Eds., pp. 237-292, American Society for Microbiology (ASM) Press, Washington, DC, USA, 2005.

[13] R. M. Atlas and R. Bartha, "Stimulated biodegradation of oil slicks using oleophilic fertilizers," Environmental Science \& Technology, vol. 7, no. 6, pp. 538-541, 1973.

[14] R. N. Austin and J. T. Groves, "Alkane-oxidizing metalloenzymes in the carbon cycle," Metallomics, vol. 3, no. 8, pp. 775-787, 2011.

[15] K. Arun, M. Ashok, and S. Rajesh, "Crude oil PAH constitution, degradation pathway and associated bioremediation microflora. An overview," International Journal of Environmental Sciences, vol. 1, no. 7, pp. 1420-1439, 2011.

[16] L. N. Ukiwe, U. U. Egereonu, P. C. Njoku, C. I. Nwoko, I. Jude, and J. I. Allinor, "Polycyclic aromatic hydrocarbons degradation techniques: a review," International Journal of Chemistry, vol. 5, no. 4, pp. 43-55, 2013.

[17] B. Coa, K. Nagarajar, and K. C. Loh, "Biodegradation of aromatic compounds: current status and opportunities for biomolecular approaches," Applied Microbiology and Biotechnology, vol. 85, no. 2, pp. 207-228, 2009.

[18] R. S. Peixoto, A. B. Vermelho, and A. S. Rosado, "Petroleumdegrading enzymes: bioremediation and new prospects," Enzyme Research, vol. 718 pages, 2011.

[19] American Public Health Association (APHA), Standard Methods for the Examination of Water and Wastewater, American Public Health Association (APHA), Washington, DC, USA, 21st edition, 2008.

[20] United States Environmental Protection Agency (USEPA), Method 8015D: Non-Halogenated Organics Using GC/FID. Revision 4, United States Environmental Protection Agency, Washington, DC, USA, 2003.

[21] H. Li, X.-L. Wang, B.-Z. Mu et al., "Molecular detection, quantification and distribution of alkane-degrading bacteria in production water from low temperature oilfields," International Biodeterioration \& Biodegradation, vol. 76, pp. 49-57, 2013.

[22] J. E. Cortes, A. Suspes, S. Roa, C. González, and H. E. Castro, "Total petroleum hydrocarbons by gaschromatography in Colombian waters and soils," American Journal of Environmental Science, vol. 8, no. 4, pp. 396-402, 2012.

[23] K. S Babu, K. Jyothi, C. K. Nancy, and A. Kashyap, "Identification and isolation of hydrocarbon degrading bacteria by molecular characterization," Helix, vol. 2, pp. 105-111, 2012.

[24] A. E. El-Tarrs, A. F. Shahaby, N. S. Awad, A. S. Bahobial, and O. A. El Abib, "In vitro screening for oil degrading bacteria and evaluation of their biodegradation potential for hydrocarbon," African Journal of Microbiology Research, vol. 6, no. 49, pp. 7534-7544, 2012.

[25] B. O. Oboh, M. O. Ilori, J. O. Akinyemi, and S. A. Adebusoye, "Hydrocarbon degrading potentials of bacteria isolated from a Nigerian bitumen (tarsand) deposit," Nature and Science, vol. 4, no. 3, pp. 51-57, 2006.

[26] J. E. Kostka, O. Prakash, W. A. Overholt et al., "Hydrocarbondegrading bacteria and the bacterial community response in gulf of Mexico beach sands impacted by the deepwater horizon oil spill," Applied and Environmental Microbiology, vol. 77, no. 22, pp. 7962-7974, 2011.

[27] A. E. Omotayo, O. Y. Ojo, and O. O. Amund, "Crude oil degradation by microorganisms in soil composts," Research Journal of Microbiology, vol. 7, no. 4, pp. 209-218, 2012.

[28] B. Gargouri, F. Karray, N. Mhiri, F. Aloui, and S. Sayadi, "Bioremediation of petroleum hydrocarbons-contaminated soil by bacterial consortium isolated from an industrial wastewater treatment plant," Journal of Chemical Technology \& Biotechnology, vol. 89, no. 7, pp. 978-987, 2014. 
[29] G. Zafra, A. Absalón, M. D. C. Cuevas, and D. C. CortésEspinosa, "Isolation and selection of a highly tolerant microbial consortium with potential for PAH biodegradation from heavy crude oil-contaminated soils," Water Air and Soil Pollution, vol. 225, pp. 1826-1835, 2014.

[30] K. Patowary, R. Patowary, C. Kalita, and S. Deka, "Development of an efficient bacterial consortium for the potential remediation of hydrocarbons from contaminated sites," Frontiers in Microbiology, vol. 7, 2016.

[31] P. A. Grażyna, M. Pacwa-Płociniczak, Z. Piotrowska-Seget, R. Brigmon, and E. Król, "Characterization of Bacillus strains Producing biosurfactants," in Environmental Sustainability, P. Thangavel and G. Sridevi, Eds., pp. 173-183, Springer, New Delhi, India, 2015.

[32] A. H. Naeem, S. Mumtaz, A. Haleem et al., "Isolation and molecular characterization of biosurfactant-producing bacterial diversity of fimkassar oil field, Pakistan," Arabian Journal for Science and Engineering, vol. 42, no. 6, pp. 2349-2359, 2017.

[33] I. Mnif, S. Mnif, R. Sahnoun et al., "Biodegradation of diesel oil by a novel microbial consortium: comparison between coinoculation with biosurfactant-producing strain and exogenously added biosurfactants," Environmental Science and Pollution Research, vol. 22, no. 19, pp. 14852-14861, 2015.

[34] Y. Liang, J. D. Van Nostrand, Y. Deng et al., "Functional gene diversity of soil microbial communities from five oil-contaminated fields in China," The ISME Journal, vol. 5, no. 3, pp. 403-413, 2011.

[35] S. Sinha, P. Chattopadhyay, I. Pan et al., "Microbial transformation of xenobiotics for environmental bioremediation," African Journal of Biotechnology, vol. 8, no. 22, pp. 6016-6027, 2009.

[36] M. Shintani and H. Nojiri, "Mobile genetic elements (MGEs) carrying catabolic genes," in Management of Microbial Resources in the Environment, A. Malik, Ed., pp. 167-214, Springer Science, Dordrecht, Netherlands, 2013.

[37] Q. Liu, J. Tang, Z. Bai, M. Hecker, and J. P. Giesy, "Distribution of petroleum degrading genes and factor analysis of petroleum contaminated soil from the Dagang Oilfield, China," Scientific Reports, vol. 5, no. 1, Article ID 11068, 2015.

[38] A. Hesham, A. M. M. Mawad, M. Y. Mostafa, and A. Shoreit, "Biodegradation ability and catabolic genes of petroleumdegrading sphingomonas koreensis strain ASU-06 isolated from Egyptian oily soil," BioMed Research International, vol. 2014, Article ID 127674, 10 pages, 2014.

[39] W. Wang, L. Wang, and Z. Shao, "Diversity and abundance of oil-degrading bacteria and alkane hydroxylase (alkB) genes in the subtropical seawater of xiamen island," Microbial Ecology, vol. 60, no. 2, pp. 429-439, 2010.

[40] R. Ding, H. Heuer, H. Zühlke et al., "Soil type-dependent responses to phenanthrene as revealed by determining the diversity and abundance of polycyclic aromatic hydrocarbon ring-hydroxylting dioxygense genes by using a novel PCR detection system," Applied and Environmentl Microbiology, vol. 76, no. 4, pp. 4765-4771, 2010.

[41] S. H. Mirdamadian, G. Emtiazi, M. H. Golabi, and H. Ghanavati, "Biodegradation of petroleum and aromatic hydrocarbons by bacteria isolated from Petroleum-Contaminated Soil," Journal of Petroleum \& Environmental Biotechnology, vol. 1, no. 1, pp. 102-112, 2010.

[42] A. Shahi, S. Aydin, B. Ince, and O. Ince, "Reconstruction of bacterial community structure and variation for enhanced petroleum hydrocarbons degradation through biostimulation of oil contaminated soil," Chemical Engineering Journal, vol. 306, pp. 60-66, $2016 \mathrm{~b}$.

[43] D. Abdel-El-Haleem, "Acinetobacter: environmental and biotechnological applications," African Journal of Biotechnology, vol. 2, no. 4, pp. 71-74, 2003.

[44] A. Shahi, S. Aydin, B. Ince, and O. Ince, "Evaluation of microbial population and functional genes during the bioremediation of petroleum-contaminated soil as an effective monitoring approach," Ecotoxicology and Environmental Safety, vol. 125, pp. 153-160, 2016a.

[45] E. Yergeau, M. Arbour, R. Brousseau et al., "Microarray and real-time PCR analyses of the responses of high-arctic soil bacteria to hydrocarbon pollution and bioremediation treatments," Applied and Environmental Microbiology, vol. 75, no. 19, pp. 6258-6267, 2009.

[46] S. M. Powell, J. P. Bowman, S. H. Ferguson, and I. Snape, "The importance of soil characteristics to the structure of alkanedegrading bacterial communities on sub-Antarctic Macquarie Island," Soil Biology and Biochemistry, vol. 42, no. 11, pp. 2012-2021, 2010.

[47] D. Jurelevicius, S. R. Cotta, R. Peixoto, A. S. Rosado, and L. Seldin, "Distribution of alkane-degrading bacterial communities in soils from king george island, maritime antarctic," European Journal of Soil Biology, vol. 51, pp. 37-44, 2012.

[48] A. G. M'rassi, F. Bensalah, J. Gury, and R. Duran, "Isolation and characterization of different bacterial strains for bioremediation of n-alkanes and polycyclic aromatic hydrocarbons," Environmental Science and Pollution Research, vol. 22, no. 20, pp. 15332-15346, 2016.

[49] L. Wang, X. Xu, and X. Lu, "Composition, source and potential risk of polycyclic aromatic hydrocarbons (PAHs) in vegetable soil from the suburbs of Xianyang City, Northwest China: a case study," Environmental Earth Sciences, vol. 75, no. 1, pp. 1-13, 2016.

[50] D. Lima-Morales, R. Jáuregui, A. Camarinha-Silva, R. Geffers, D. H. Pieper, and R. Vilchez-Vargas, "Linking microbial community and catabolic gene structures during the adaptation of three contaminated soils under continuous longterm pollutant stress," Applied and Environmental Microbiology, vol. 82, no. 7, pp. 2227-2237, 2016.

[51] F. Thomas, C. Lorgeoux, P. Faure, D. Billet, and A. Cébron, "Isolation and substrate screening of polycyclic aromatic hydrocarbon degrading bacteria from soil with long history of contamination," International Biodeterioration \& Biodegradation, vol. 107, pp. 1-9, 2016.

[52] P. He, L. Li, J. Liu, Y. Bai, and X. Fang, "Diversity and distribution of catechol 2, 3, dioxygenase genes in surface sediments of the Bohai sea," FEMS Microbiology, vol. 363, no. 10, pp. 3454-352, 2016.

[53] I. Kasuga, F. Nakajima, and H. Furumai, "Diversity of catechol 2,3-dioxygenase genes of bacteria responding to dissolved organic matter derived from different sources in a eutrophic lake," FEMS Microbiology Ecology, vol. 61, no. 3, pp. 449-458, 2007.

[54] O. F. Olukunle, O. Babajide, and B. Boboye, "Effects of temperature and $\mathrm{pH}$ on the activities of catechol 2,3-dioxygenase obtained from crude oil contaminated soil in ilaje, ondo state, Nigeria," The Open Microbiology Journal, vol. 9, no. 1, pp. 84-90, 2015.

[55] R. Baruah, D. J. Kalita, B. K. Saikia, A. Gautam, A. K. Singh, and H. P. D. Boruah, "Native hydrocarbonoclastic bacteria and hydrocarbon mineralization processes," International Biodeterioration \& Biodegradation, vol. 112, pp. 18-30, 2016. 